
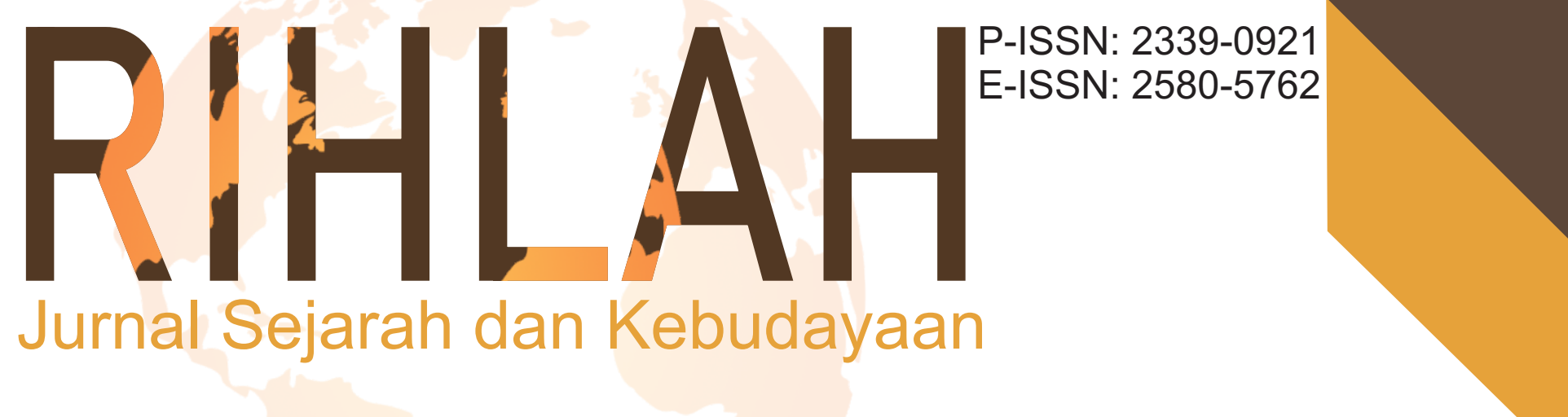

Article

Kebangkitan Kesultanan Ternate pada Era Reformasi 1998-2002 Rustam Hasyim, Oktosiyanti MT Abdullah, Siti Rahia H. Umar

Kondisi Politik Persia pada Era Dinasti Qajar 1796-1834 M Arafah Paramasto

Sultan Abdul Qahir dalam Pengembangan Islam di Bima Rahmat, Nurwahidah

Eksistensi Maccera Manurung dalam Perspektif Nilai Islam Sitti Fatimah Dwi Putri Islam dalam Tradisi Pernikahan Nuraeni

The Developments and Problems of Muslims in Australia Syamzan Syukur, Syamhi Muawwan, Syarifah Fauziah

Book Review

Historiografi Korupsi di Indonesia: Resensi Buku Korupsi dalam Miftakhuddin

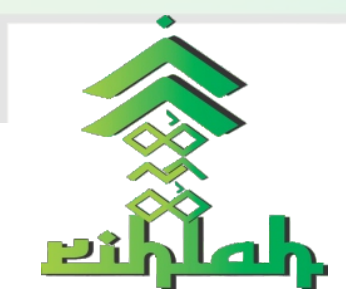




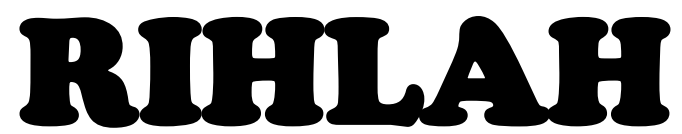

Jurnal Sejarah dan Kebudayaan

\begin{tabular}{|c|c|}
\hline Editor in Chief & Dr. Rahmat, M.Pd. \\
\hline Managing Editor & Mastanning, S.Hum, M.Hum. \\
\hline Editorial Board & $\begin{array}{l}\text { Nur Ahsan Syukur, S.Ag, M.Si. } \\
\text { Muh. Iqbal S.Hum, M.Hum. } \\
\text { Chaerul Munzir, S.Hum, M.Hum. } \\
\text { Lydia Megawati, S.Hum, M.Hum. } \\
\text { Muhammad Husni, S.Hum, M.Hum. } \\
\text { Zaenal Abidin, S.S., M.H.I. } \\
\text { Chusnul Chatimah Asmad, S.IP, M.M. } \\
\text { Muhammad Arif, S.Hum, M.Hum. }\end{array}$ \\
\hline Desain Grafis & Nur Arifin, S.IP. \\
\hline Secretariat & Safaruddin, S.Hum. \\
\hline Reviewers & $\begin{array}{l}\text { Prof. Dr. H. Abd. Rahim Yunus, M.A. } \\
\text { Prof. Dr. H. Ahmad M. Sewang, M.Ag. } \\
\text { Dr. Hj Syamzan Syukur, M.Ag. } \\
\text { Dr. Nasruddin Ibrahim. } \\
\text { Dr. Abd. Rahman Hamid. } \\
\text { St. Junaeda, M.Hum. } \\
\text { Dr. Syamhari, M.Pd. } \\
\text { Dr. A. Sukri Samsuri, M.Pd. }\end{array}$ \\
\hline
\end{tabular}

Alamat Redaksi dan Tata Usaha : Jurusan Sejarah dan Kebudayaan Islam Fakultas Adab dan Humaniora UIN Alauddin Makassar, Jln. Sultan Alauddin No. 36 Samata Gowa Tlp. 0411-841879 Fax. 0411-822140 (Kampus II) E.Mail. rihlah@uin-alauddin.ac.id

Jurnal Rihlah terbit dua kali dalam setahun, bulan Juni dan bulan Desember berisi kajian tentang Sejarah dan Kebudayaan, baik dari hasil penelitian maupun tulisan ilmiah lainnya.

Penyunting menerima tulisan yang belum pernah diterbitkan oleh media cetak lain. Naskah diketik spasi $1 \mathrm{~cm}$ pada kertas berukuran A4 dengan tulisan berkisar 12-23 halaman. Naskah yang masuk dievaluasi oleh Dewan Penyunting. Penyunting dapat melakukan perubahan pada tulisan yang dimuat untuk keseraganan format, tanpa mengubah maksud dan konten tulisan. 


\section{Daftar Isi}

Rustam, Oktosiyanti, Rahia

69-103

Kebangkitan Kesultanan Ternate pada Era Reformasi 1998-2002

Arafah Pramsto

104-125

Kondisi Politik Persia pada Era Dinasti Qajar 1796-1834

Rahmat, Nurwahidah

126-136

Sultan Abdul Qahir dalam Pengembangan Islam di Indonesia

Sitti Fatimah Dwi Putri

$.137-148$

Eksistensi Maccera Manurung dalam Perspektif Nili Islam

Nuraeni

$.149-158$

Islam dalam Tradisi Pernikahan

Syamzan, Syamhi, Syarifah 159-167

The Developments and Problems of Muslims in Australia

Miftakhuddin 168-172

Historiografi Korupsi di Indonesia: Resensi Buku dalam Silang

Sejarah Indonesia 


\title{
THE DEVELOPMENTS AND PROBLEMS OF MUSLIMS IN AUSTRALIA
}

\author{
Syamzan Syukur, Syamhi Muawwan Djamal, Syarifah Fauziah \\ Univesitas Islam Negeri Alauddin Makassar \\ zansyukur@yahoo.com
}

\section{Abstract}

This paper shows that historians have different views about the early arrival of Islam in Australia; some argue that Islam entered Australia in the 9th century BC. Those that believe in the 10th century BC were brought by Arab traders. Besides, some mention below by Muslim Bugis fishermen who traveled by sailboat to collect taripang (a kind of sea slug) on the Gulf of Carpentaria in the 17th century BC. While the development of Islam in Australia started appears from 1976 to 1986 the Muslim community in Australia rose to a three-fold. Increasing the quantity of Muslims in Australia is generally dominated by immigrants from the countries of the Muslim majority. Activity and religious activity continues to writhe mainly due to the support and role of Islamic organizations. As for the problems faced by Muslims in Australia is coming from a non-Muslim society of Australia; Persistence of Muslims to practice their religion, sometimes considered a fanatic attitude and could not cooperate. Another problematic faced by Muslims is related to a misunderstanding of Islam. Most of Australian non-Muslims regard that Islam is a violent religion. This perspective is connected by the collapse of World Trade Center (WTC). The method of this research is descriptive-analytic qualitative study that utilizes library resources to acquire, manage and analyze data.

Keywords: Progress, Problems and Muslims in Australia

\section{Abstrak}

Tulisan ini menunjukkan bahwa, para sejarawan memiliki pandangan yang berbeda mengenai awal masuknya Islam di Australia; sebagian berpendapat bahwa Islam masuk ke Australia pada abad ke-9 masehi. Adapula yang berpendapat pada abad ke-10 masehi yang dibawah oleh pedagang-pedagang Arab melalui pantai Australia. Selain itu adapula yang menyebutkan di bawah oleh nelayan muslim Bugis yang berkelana dengan perahu layar untuk mengumpulkan taripang (semacam siput laut) dari teluk Carpentaria pada abad ke-17 masehi. Sedangkan perkembangan Islam di Australia mulai Nampak sejak tahun 1976 sampai tahun 1986 komunitas kaum muslimin di Australia meningkat mencapai tiga kali lipat. Peningkatan kuantitas kaum muslimin di Australi pada umumnya didominasi oleh para imigran dari negera-negara mayoritas muslim. kegiatan dan aktivitas keagamaan pun terus menggeliat terutama karena dukungan dan Peranan organisasi-organisasi Islam. Adapun problematika yang dihadapi kaum muslimin di Australia adalah datangnya dari masyarakt non-muslim Australia; Ketekunan 
umat Islam menjalankan ajaran agamanya, terkadang dianggap sebagai sikap fanatic dan tidak bisa diajak kompromi. Problematika lain yang dihadapi kaum muslimin adalah berkaitan dengan kesalah pahaman tentang Islam. Kebanyakan non-muslim Australia menganggap bahwa Islam adalah agama kekerasan. Persfektif ini mereka hubungkan dengan peristiwa runtuhnya gedung WTC. Metode penelitian ini merupakan penelitian kualitatif deskriptif-analitik denhan memanfaatkan sumber perpustakaan untuk memperoleh, mengelola dan menganalisis data.

Kata Kunci: Perkembangan, Problematika, Umat Islam di Australia

\section{Background}

History has recorded that the victors of World War I (1815) were European countries. The consequence of this victory was the vast countries both in Asia and in Africa were ruled by European countries. World War I was considered the final round of the conquest of the West against the Islamic states or Muslim-majority countries. In this period also ended the Caliphate in the Islamic government.

What's interesting about this event, after World War I, there was a massive migration of Muslims. The immigrants were motivated to leave their home, their country to seek a better life in the various corners of the world. The author considers that the Muslim migration was inspired by the prophet Muhammad's movement (hijrah) to the city of Yastrib which was renamed as Madinatul Munawwarah or better known as Madinah. ${ }^{1}$ Rasulullah SAW decided to move along with the Muslims to Medina, because Muslims in Mecca faced intimidation and boycott in both political and economic sectors by Quraish.

As experienced by the Muslims at the time of the Prophet Muhammad in Mecca, Muslim-majority countries after World War I were also experiencing political and economic uncertainty. Furthermore the increased escalation of regional conflicts. Then a number of these countries migrate or emigrate to Western countries. Therefore, after World War I, Muslim immigrants can easily be found in several countries, such as the United State of America, England, Germany, Norwegia, Italy, New Zealand, Canada, and Australia. These countries are known as the sizeable Muslim-minority countries. According to the analysis of authors, Muslim immigrants have a major role in the development of Muslims in Western and European countries.

In specific, the Australian population is approximated 16,849,496 people. From that number, $50 \%$ are Christian and the rest converted to other religions such as Islam that is placed in the second place and later Anglican, Taoism, Shinto, and others. As a Muslim-minority country, the Muslim community in Australia would strive or struggle that Islam has a strong presence in Australia. The struggle of the Australian Muslims of Australia to do the missionary endeavor of Islam or (syi'ar Islam) should be appreciated. Thus Islam has progressed from time to time.

${ }^{1}$ Badri Yatim, History of Islamic Civilization, Cet. 1 (Jakarta: King Grafindo Persada, 1994), p. 25 
On the other hand, the problems faced by the Muslims as the majority religion are also unavoidable. Therefore stressing the discussion of this paper is the development and problems of Muslims in Australia.

\section{The Early History of Islam in Australia}

It seems that historians have different views about the early arrival of Islam in Australia. Some argue that Islam came to Australia in the 9th century BC. Some say that Islam entered Australia in the 10th century BC were brought by Arab traders through the Australian coast. ${ }^{2}$ Others state that Islam came to Australia in the 15th century by fishermen from Indonesia, especially from Makassar and Maluku.

In addition, some mention that Islam entered Australia under the Muslim Bugis fishermen who traveled by sailboat to collect taripang (a kind of sea slug) on the Gulf of Carpentaria in the 17th century BC. The span of contact with Aboriginal (Native Australia), Bugis fishermen got along and had an influence on art, culture and including religion. ${ }^{3}$ According to the writer, the thought of Islam had entered into Australia since the 17th century, and already there was an interaction between Islam and the Indigenous peoples of Australia (Aborigines). On the other hand it seems the presence of Islam around four centuries ago had a significant impact related to the quantity of the Australian community who embraced Islam. Thus the increase in the quantity of the Muslim community in Australia is generally dominated by the immigrants.

In 1860, when Dost Muhammad, a camel trader from Karachi-Pakistan brought 24 camels for sale in the country. No data found, why explorers Muslim choose Australia as a place to trade camels. But when viewed from its geographical, Australia is the desert region that dominates the area. The authors considered that the camel is an animal that is needed in Australia. Perhaps this is the reason Dost Muhammad traded camels while preaching Islam in Australia. ${ }^{4}$

In the next period, following the arrival of immigrants from Albania, Yugoslavia, Turkey, Cyprus Palestine, China, Syria, Saudi Arabia, India Bangladesh, Malaysia, Indonesia, and others. Muslim immigrants who come to Australia generally work as laborers in mining, factories, and plantations as well as some who work as traders. ${ }^{5}$

The presence of Muslim immigrants in Australia would give an effect on the development of Islam there. They are self-erecting settlements and mosques. They

${ }^{2}$ M.Ali Kettani, Muslim: In The Word Today, translated by Zarkawi Soejoeti headings: Muslim Minorities in the World Today (Jakarta: Grafindo persada, 2005), p. 309

${ }^{3}$ Nurfu'ad Ahmad, Muslim minorities in non-Muslim countries, (Surabaya: UNISA Press, 2014), p. 170

${ }^{4}$ Deddy Mulyana, Islam and people of Indonesia in Australia, (Jakarta: PT Logos Discourse Studies, 2000), h.20

${ }^{5}$ Munjin, "Muslim Minorities and Gender Discourse in Australia", Journal of Gender and Child Studies, Vol.4 No. 1, (Porwokerto: STAIN Porwekerto Press, 2009), p. 144 
build mosques, among others in Broken Hill in 1981, in Pert 1904 and 1907. Brisbane Adelaide Mosque which was built in 1889 until now still works. Mosques built by the immigrants including Islamic syi'ar which give effect to the development of Islam in Australia

\section{The Development of Islam in Australia}

According to Sheppard, the Muslims have already lived in Australia for more than half a century, but the Islamic community was not developing in Australia until 1950. That is after World War I as the wave of immigration from the Middle East countries. The subsequent years, the number of Muslim were increased to immigrate. They were including the Turks Muslims who came with the support of the government of Turkey. Similarly, Lebanese Muslims, they fled the country because of avoiding civil war after 1975. So between 1976 and 1986 the Muslim community in Australia rose to a three-fold. Noted Lebanese Muslims in Australia reached $80 \%$ from the Muslims population in Australia and 20\% of them are Muslims from Arab countries, South Asia, Southeast Asia, and other countries. ${ }^{6}$

Before the 1980s, the population of Muslims in Australia were around 41.470 from Turkey, 21080 from Indonesia, 18,500 from Egypt, 5,950 from Syria and 5,370 from Pakistan, and a fewer number of countries such as Yugoslavia, Malaysia, and Singapore. Based on these data, the Muslim population of Indonesia ranks second after Muslim Turkey. Thus it can be stated that the Muslim community from Indonesia chose an important war in spreading Islam in Australia.

Based on the census, the number of Muslims in Australia since 1986 were about 10523 inhabitants. Notwithstanding the Australian Federation of Islamic Councils claimed that in the 1980s, at least the Muslim community had reached 250,000. This figure when is confirmed into the population of Australia, it reached $0.7 \%$ of the Muslim community, and of course, this number continues to increase. Islam is considered a rapidly expanding religion. According to the analysis of the writer, the significant growth of Islam is caused of the consideration as a religion that can answer the challenges of modern society such as the role and function of the family in the Islamic perspective, the concept of birr al-walidain, the concept of gender in Islamic perspective and others. Therefore, since 1981, Islam had become the second-largest religion after Christianity. The great progress of Islam in this Kangaroo State cannot be separated from the role of Islamic Da'wah organizations, Islamic education, and other channels.

As a result of the Islamic development in Australia, the waves of religious activity continue to squirm. It cannot be separated from the role of AFIC and its supporting organizations or partner organizations. Such as the Islamic Council, and

${ }^{6}$ Indira Kartini, "Muslim minorities in Australia and the UK", Journal of Political Research, Vol. 3 No. 1 (Jakarta: LIPI, 2006), p. 98 1, p. 99

\footnotetext{
${ }^{7}$ Indira Kartini, "Muslim Minorities in Australia", Journal of Political Research, Vol.3 No.
} 
Muslim Women of Australia that have given a great influence on the development of Islam. These organizations contribute to provide the facilities and infrastructure needed by the Muslim community in particular to support the implementation of Islamic teachings. For instance, the mosques and educational facilities continue to grow over the years.

Mosque was built in many corners, there are more than 100 mosques. In 1997, a mosque in six Agnes Street, Burada, had been inaugurated. This mosque is a big and grand mosque. The history of the existence of this mosque is also interesting because it is a former church that was bought independently by Muslims for 165,000 dollars.

The government of Australia has also contributed to the development of Islam in Australia. the government has authorized the Muslims to practice her faith for not disturbing other religions (religious tolerance).

Western countries and Europe known as countries that uphold human rights, including the right to worship according to their beliefs. At this point, the quantity of Muslims is a minority, has given space to pro-actively and effectively carry out the teachings of Islam such as daily prayers, charity and fasting without constraints, even the Hajj can be implemented through an Australian visa.

In carrying out the teachings of Islam to its adherents in Australia, there was no dichotomy of government. Muslims as religious minorities in Australia but it seems Muslims in doing syi'ar Islam are not flashy, but on the other side of the mosques that exist in Australia remains crowded with Muslims when azan reverb or echo, especially during Ramadhan. This method may cause sympathetic to Australians. So later, many residents of Australia who are interested in Islam.

The rise of Islam in Australia is not only seen in the observance and obedience of Muslim communities in carrying out Islamic teachings. But it also marked the emergence of various Islamic institutions. Islamic institutions make a wide range of sporting nuanced Islamic. So the Muslim community feels proud and confident even though they are in Muslim minority countries.

The use of Islamic symbols also be an interesting thing to be assessed in Australia's Muslim minority communities; many non-Muslim communities of Australia are interested in Islam. The converts change their name with Islamic names so that Islamic symbolism is also attached to the converts. By using the name of Islam influence the behavior of converts, such as away from disobedience and back on obedience and piety, good relationships and doing silaturrahmi with a friendly social interaction.

\section{Problems Faced by Muslims in Australia}

Although Muslims have the passion and motivation in performing their religious rituals, another problem encountered is the coming from non-Muslim Australian society. Persistence Muslims practice her faith considered a fanatic and unbiased attitude to compromise.

Hijab (veil) which is a symbol for Muslim women may result in limited access in public domain such as the labor market, care, and services. 
Samina Yasmen, exemplifies a case that an Australian woman in her youth, recognizing that hijab or headscarf is an obstacle in getting jobs. A veiled Muslim woman can only work as a secretary or seller. In this work, the hijab is an obstacle in the workplace because it can cause customers or customer fear. Very often Muslim women who applied for a job rejected because of wearing hijab.

Another problematic faced by Muslims in Australia is related to a misunderstanding of Islam. Most non-Muslim Australians regard that Islam is a violent religion. This perspective connects with the character of Osama bin Laden as well as several cases of terrorism such as the Bali Bombing Tragedy masterminded by radical groups that occurred in October 2002. In this tragedy, $60 \%$ of the victims were Australians died. It was the sorrow for the people of Australia, so they do not easily forget. Likewise, alarmed by the collapse of the WTC buildings on September $11 .^{8}$

The Bali bombing tragedy, causing a strong reaction from the Australian government and assume that the Muslims are terrorists. The anti-terror movement emerged. ${ }^{9}$ Muslims Australia when it was facing the problem of highly complicated. Newspapers and televisions make this tragedy in the headlines. Internet sites also raised the news that Muslims in Australia "panic". Australian Muslims were really in danger, they are not free to travel in and out of the house. Because they were subjected to insults, hatred and anger Australians.

Post-Tragedy Bali bombings, Australian police implement a search and examination of a number of Muslims, especially citizens of Indonesia because they suspect the involvement of Jami'ah Islamiyah (JI).

Sunday Herald Sun, one of newspaper in Australia reported attacks against Muslims in Victoria. The attack was not only aimed at Muslim men but also to women, especially women who wear headscarves. Even Muslims are not given access to use public transport (bus), while the Muslims cars vandalized, burnt and then the owner mistreated, humiliated and other violent acts.

According to Yasser Soliman, the accidents were experienced by Australian Muslims, such as insults, harsh treatment and other acts of violence are likened to an iceberg. Persecution and violence were reported to the police or what informed by the mass media is only a small part. There are still many events or an act of violence that is not published.

In handling various cases of violence, there was not found an advocacy from Islamic associations, whether in national or international. In terms of their involvement in the protection of the minority Muslim population is needed, in order to realize peace and tranquility of Muslims minorities. 1, p. 99

${ }^{8}$ Indira Kartini, "Muslim Minorities in Australia", Journal of Political Research, Vol.3 No. 1, p. 99

${ }^{9}$ Indira Kartini, "Muslim Minorities in Australia", Journal of Political Research, Vol.3 No. 
In this context, it is in fact that Australia has established the organization Society of Muslims. In 1965, a national organization founded in Australia and evolved in 1975 into a three-level structure consisting of local associations, eight state assembly.

A new organization called The Australian Federation of Islamic Councils (AFIC) as mentioned previously, provides the educational services, cultural and religious, although local associations still have autonomy. ${ }^{10}$ The function of Australian Federation of Islamic Councils (AFIC) is to represent the Muslims of Australia, both in agencies in Australia itself and abroad. It also provides kosher certificates on livestock. Certainly, the organizations or associations are chaired by Muslims and received support from countries of the Middle East. ${ }^{11}$ It is therefore natural that Australians feel suspicion and negative thinking of the existence of Islam in Australia. The fact also shows that the association of Muslim organizations received financial support from Saudi Arabia to build mosques in Australia. The assistance of the Middle East country is increasingly emerging by the tendency of Australians to alienate, eliminate and erase the Islamic identity.

The other problems faced by Muslims in Australia are the issues related to the family environment. Living in a country predominantly non-Muslim and secular country, Australian Muslims are demanded to actively defend their Islamic identity. In addition, the Australian cultures, such as wearing irreligious dress and clubbing with forbidden drink, and being lead to disobedience association, are becoming the challenge for Muslim families in educating their children.

\section{Conclusion}

Based on the previous descriptions, the authors formulated the followinxg conclusions:

1. Historians have different views about the early arrival of Islam in Australia; some argue that Islam entered Australia in the 9th century BC. Those that believe in the 10th century BC were brought by Arab traders through the Australian coast. Another opinion said that in the 15th century by fishermen from Indonesia, especially from Makassar and Maluku. Besides some mention below by Muslim Bugis fishermen who traveled by sailboat to collect taripang (a kind of sea slug) on the Gulf of Carpentaria in the 17th century BC. The span of contact with Aboriginal (Native Australia), Bugis fishermen hang out and give effect to the arts, culture and including religion.

2. From 1976 to 1986 the Muslim community in Australia rose to a three-fold. Increasing the quantity of Muslims in Australia is generally dominated by

${ }^{10}$ M.Ali Kettani, Muslim: In The Word Today, translated by Zarkawi Soejoeti headings: Muslim Minorities in the World Today (Jakarta: Grafindo persada 2005

${ }^{11}$ Munjin, "Muslim Minorities and Gender Discourse in Australia", Journal of Gender and Child Studies, Vol.4 No. 1, p. 144 
immigrants from the countries of Muslim majority; from Lebanon reached $80 \%$ of the Muslim population in Australia and 20\% of them are Muslims from Arab countries, South Asia, Southeast Asia, and other countries. Along with the pace of development of Islam in Australia, activities and religious activities continue to stretch mainly due to the support and role of Islamic organizations such as AFIC. and the Islamic Council, Muslim Women of Australia. These organizations contribute in providing the facilities and infrastructure needed by Muslims in particular to support the implementation of Islamic teachings. Such as mosques and educational facilities that continue to grow from year to year.

3. Problems faced by Muslims in Australia is coming from a non-Muslim society of Australia; Persistence of Muslims to practice their religion, sometimes considered a fanatic and unbiased attitude to compromise. Another problematic faced by Muslims is related to a misunderstanding of Islam. Most non-Muslim Australians regard that Islam is a violent religion. This perspective is connected with the character of Osama bin Laden and Tragedy in the October 2002 Bali bombings.

\section{REFERENCES}

Deddy Mulyana, Islam and people of Indonesia in Australia, Jakarta: PT Logos Discourse Studies, 2000

Kartini Indira, "Muslim minorities in Australia and the UK", Journal of Political Research, Vol. 3 No. 1, Jakarta: LIPI 2006

Kettani, M.Ali, Muslim: In The Word Today, translated by Zarkawi Soejoeti with Title: Minority Muslims in the World Today Jakarta: Grafindo persada 2005

Macknight, CC Voyage to Marege: Maccassan trepangers in northern Australia. Melbourne: Melbourne University Press. 1976. Diterjemhkan by Anwar Jimpe Rachman, Ihsan Natsir. Napier: Publisher Ininnawa. 2017.

Mangandaralam, Syahbuddin. Know of nearby Australia, Kangaroo Continent. Bandung: PT Young Rosdakarya. 1995. Fourth Printing.

Munjin, "Muslim Minorities and Gender Discourse in Australia", Journal of Gender and Child Studies, Vol.4 No. 1, (Porwokerto: STAIN Porwekerto Press, 2009

Nurfu'ad, Ahmad, Muslim minorities in non-Muslim countries, Surabaya: UNISA Press, 2014 
Saeed, Abdullah. Islam in Australia. South Australia: Griffin Press. 2003.

Siboro, Julius. Australia's history: from the formation of the Commonwealth of Australia to the Formation of Regional Cooperation with the Countries of Asia and the Pacific. Yogyakarta: Waves. 2018.

Yacob, Touku Khalidin, Malay Muslim Australian Inventors: Portrait of Indonesian Muslims in Continent Kangaroo (Jakarta: MINA Publishing House: 2017

Orphans, Badri, History of Islamic Civilization, Cet. 1 (Jakarta: King Grafindo Persada, 1994 